\title{
HUBUNGAN TINGKAT PENGETAHUAN DENGAN KECEMASAN IBU HAMIL DI MASA PANDEMI COVID-19 DI PRAKTEK MANDIRI BIDAN DENPASAR SELATAN
}

\author{
(The Relationship Of Knowledge Level With Pregnant Mother's Anxiety During \\ The Covid-19 Pandemic In Independent Midwife Practices, Denpasar Selatan) \\ Ni Made Nurtini*, Komang Ayu Purnama Dewi**, Ni Ketut Noriani*** \\ $\left.\left.\left.{ }^{*}\right),{ }^{* *}\right),{ }^{* *}\right)$ ITEKES BALI, Jalan Tukad Balian No 180 Renon Denpasar \\ Email: adenurtini82sanur@gmail.com
}

\begin{abstract}
ABSTRAK
Latar Belakang : Pandemi COVID-19 dialami oleh seluruh negara di dunia, pelayanan kesehatan maternal dan neonatal terkena dampak baik secara akses maupun kualitas. Tujuan dari penelitian ini adalah menganalisa hubungan tingkat pengetahuan dengan kecemasan ibu hamil di masa pandemi Covid-19.

Metode: desain penelitian ini adalah analitik cross sectional. Populasi semua ibu hamil yang melakukan pemeriksaan kehamilan di Praktek Mandiri Bidan (PMB) Denpasar Selatan, pada bulan Januari sampai Februari 2021. Pengambilan sample dilakukan secara incidental sampling. Jumlah sample yang digunakan 100 orang ibu hamil. Intrumen pengumpulan data dalam penelitian ini adalah kuesioner dengan google form (online). Analisa bivarite yang digunakan chi-square.

Hasil: penelitian ini responden paling banyak memiliki pengetahuan baik sejumlah 92 responden $(92 \%)$, responden paling banyak dikategorikan normal untuk kecemasan sejumlah 96 responden $(96 \%)$ dan 4 responden yang mengalami kecemasan ringan. Berdasarkan nilai nilai $\mathrm{p}<0,05$ dapat diambil kesimpulan bahwa ada hubungan antara tingkat pengetahuan dengan kecemasan ibu hamil di masa pandemi Covid-19

Kesimpulan: ada hubungan antara tingkat pengetahuan dengan kecemasan ibu hamil di masa pandemi Covid-19. Ibu hamil lebih aktif untuk mencari informasi terbaru yang berkaitan dengan kesehatan ibu dan janin, terlebih lagi untuk mempersiapkan diri dalam menghadapi persalinan masa pandemi covid-19
\end{abstract}

Kata kunci : pengetahuan, ibu hamil, kecemasan, covid-19

\section{ABSTRACT}

Background: The COVID-19 pandemic is experienced by all countries in the world, maternal and neonatal health services are affected both in terms of access and quality. The purpose of this study was to analyze the relationship between the level of knowledge and the anxiety of pregnant women during the Covid-19 pandemic.

Methods: The design of this study was cross sectional analytic. The population is all pregnant women who carry out pregnancy check-ups at the Independent Midwife Practice (PMB) South Denpasar, from January to February 2021. Sampling is done by incidental sampling. The number of samples used was 100 pregnant women. The data collection instrument in this study was a questionnaire with a google form (online). Bivarite analysis used chi-square.

Results: In this study, the most respondents had good knowledge of 92 respondents (92\%), the most respondents were categorized as normal for anxiety, 96 respondents (96\%) and 4 
respondents who experienced mild anxiety. Based on the $p$ value $<0,05$, it can be concluded that there is a relationship between the level of knowledge and anxiety of pregnant women during the Covid-19 pandemic.

Conclusion: there is a relationship between the level of knowledge and anxiety of pregnant women during the Covid-19 pandemic. Pregnant women are more active in seeking the latest information related to the health of the mother and fetus, even more so to prepare for childbirth during the COVID-19 pandemic.

Keywords: knowledge, pregnant women, anxiety, covid-19

\section{LATAR BELAKANG}

Kematian ibu dan kematian neonatal di Indonesia masih menjadi tantangan besar, apalagi pada saat situasi bencana. Angka kematian ibu di Indonesia tahun 2019 sebanyak 4.221 kasus per 100.000 kelahiran hidup (4.2\%). Sedangkan angka kematian ibu di Provinsi Bali tahun 2019 sebesar 67,6 per 100.000kelahiran hidup, jika dibandingkan dengan tahun 2020 sebesar 68 per 100.000 kelahiran hidup dari data menunjukkan terjadi peningkatan kasus kematain ibu hamil di Provinsi Bali (Dinkes Provinsi Bali, 2020). Saat ini, Indonesia sedang menghadapi bencana nasional non alam COVID-19 sehingga pelayanan kesehatan maternal dan neonatal menjadi salah satu layanan yang terkena dampak baik secara akses maupun kualitas. Dikhawatirkan, hal ini menyebabkan adanya peningkatan morbiditas dan mortalitas ibu dan bayi baru lahir. Dalam situasi pandemi COVID-19 ini, banyak pembatasan hampir ke semua layanan rutin termasuk pelayanan kesehatan maternal dan neonatal. Seperti ibu hamil menjadi enggan ke puskesmas atau fasiltas pelayanan kesehatan lainnya karena takut tertular, adanya anjuran menunda pemeriksaan kehamilan dan kelas ibu hamil, serta adanya ketidaksiapan layanan dari segi tenaga dan sarana prasarana termasuk Alat Pelindung Diri (Kemenkes RI, 2020).

Kecemasan adalah perasaan dan respon emosional seseorang terhadap suatu ancaman. Kecemasan terkait dengan perasaan tidak pasti, tidak berdaya, isolasi dan ketidakamanan. Kecemasan bersifat subyektif dan tidak memiliki obyek secara spesifik yang tidak dapat dinilai secara langsung. Kapasitas perasaan cemas diperlukan untuk bertahan hidup dengan bisa menghadapi dan belajar dari pengalaman kecemasan yang dialami (Stuart, 2013). Pada umumnya seorang ibu yang mengalami kehamilan untuk pertama kalinya akan merasa senang dan semakin tinggi rasa ingin tahu terhadap perubahann dirinya dan perkembangan janin. Tetapi disaat yang sama timbul pula rasa cemas dalam diri ibu hamil (Shodiqoh, 2014). Selain berdampak pada proses persalinan, kecemasan pada ibu hamil juga dapat berpengaruh pada tumbuh kembang anak. Kecemasan yang terjadi terutama pada trimester ketiga dapat mengakibatkan penurunan berat badan lahir (Shahhosseini,dkk,2015).

Menurut beberapa faktor yang berhubungan dengan kecemasan yaitu pengetahuan, psikologi, ekonomi, pengalaman, dukungan keluarga serta dukungang suami. Ibu hamil dengan usia kurang dari 20 tahun atau lebih dari 35 tahun merupakan usia hamil resiko tinggi karena dapat terjadi kelainan atau gangguan pada janin, sehingga dapat menimbulkan kecemasan pada ibu hamil tersebut (Pieter, 2011). Dalam menyelesaikan masalah ibu hamil yang satu dengan yang lain berbeda -beda, strategi coping yang dilih pun berbeda. Jika individu memiliki mekanisme coping yang cukup maka individu tersebut akan terbebas dari kecemasan, sebaliknya apabila mekanisme yang dimiliki kurang maka individu tersebut akan mengalami kecemasan (Nursalam, 2016).

Uraian diatas membuat peneliti tertarik untuk meneliti tentang hubungan tingkat pengetahuan dengan kecemasan ibu hamil di masa pandemi Covid-19 Di Praktek Mandiri Bidan Denpasar Selatan.

\section{METODE}

Desian penelitian ini adalah analitik cross sectional. Populasi semua ibu hamil yang melakukan pemeriksaan kehamilan di Praktek Mandiri Bidan (PMB) Denpasar Selatan, pada bulan Januari sampai Februari 2021. Pengambilan sample dilakukan secara incidental sampling. Jumlah sample yang digunakan 100 orang ibu hamil. Intrumen pengumpulan data dalam penelitian ini adalah kuesioner dengan google form (online). Kuesioner tingkat pengetahuan dikembangkan sendiri oleh peneliti dengan melakukan uji reliabelitas dan validitas dengan hasil uji reliabilitas variabel

Jurnal Riset Kesehatan Nasional hal. 95 
pengetahuan didapatkan hasil nilai Cronbach's Alpha sebesar 0,709 >0,60 sedangkan uji validitas dengan $\mathrm{n}=20$ dengan signifikasi 5\% di dapatkan $\mathrm{r}$ tabel 0,444 . Hasilnya adalah dari 20 item pertanyaan dinyatakan valid semua dengan nilai $r$ hitung $\geq 0,444$. Kuesioner tingkat kecemasan adalah kuesioner sudah baku menggunakan sumber Kuesioner Depression Anxiety Stres Scale 42 (DASS 42). Penelitian ini juga melalui Ethical Clearance. di Analisa bivarite yang digunakan chi square.

HASIL

Karakteristik Responden

Tabel 1 Karakteristik Responden $(\mathrm{n}=100)$

\begin{tabular}{|c|c|c|c|c|}
\hline $\begin{array}{l}\text { Ting- } \\
\text { kat }\end{array}$ & \multicolumn{2}{|c|}{$\begin{array}{l}\text { Tingkat } \\
\text { kecemasan }\end{array}$} & $\begin{array}{l}\text { tot } \\
\text { al }\end{array}$ & $\overline{\mathbf{P}}$ \\
\hline $\begin{array}{l}\text { penge } \\
\text { tahua } \\
\text { n }\end{array}$ & $\begin{array}{l}\text { Nor } \\
\text { mal }\end{array}$ & $\begin{array}{l}\text { Ringa } \\
\mathrm{n}\end{array}$ & & 0,001 \\
\hline Baik & 91 & 1 & 92 & \\
\hline $\begin{array}{l}\text { Cuk } \\
\text { up }\end{array}$ & 5 & 3 & 8 & \\
\hline
\end{tabular}

Berdasarkan tabel 1 diatas, usia terbanyak adalah 20-35 tahun (84\%), pendidikan terbanyak SMA (64\%), terbanyak bekerja $(75 \%)$, usia kehamilan TW II terbanyak (62\%), paritas terbanyak primigravida (59\%).

Gambaran tingkat pengetahuan ibu hamil tentang kehamilan pada masa pandemic Covid-19

Tabel 2 Gambaran tingkat pengetahuan ibu hamil tentang kehamilan pada masa pandemic Covid-19 (n=100)

\begin{tabular}{lll}
\hline $\begin{array}{l}\text { Tingkat } \\
\text { pengetahua } \\
\text { n }\end{array}$ & $\begin{array}{l}\text { Frekuensi } \\
\text { (f) }\end{array}$ & $\begin{array}{l}\text { Persen } \\
\text { (\%) }\end{array}$ \\
Baik & 92 & 92 \\
Cukup & 8 & 8 \\
\hline
\end{tabular}

Berdasarkan informasi yang ditampilkan pada tabel 4.2 gambaran tingkat pengetahuan ibu hamil tentang kehamilan pada masa pandemic Covid-19 yang paling memiliki pengetahuan baik, yaitu 92 responden (92\%).

Gambaran tingkat kecemasan ibu hamil pada masa pandemic Covid-19

Tabel 3 Tingkat Kecemasan Ibu Hamil pada masa pandemi Covid-19 $(\mathrm{n}=100)$

\begin{tabular}{lll}
\hline Tingkat & Frekuens & Persen \\
Kecemasan & i (f) & $(\%)$ \\
Normal & 96 & 96 \\
Ringan & 4 & 4 \\
\hline
\end{tabular}

Berdasarkan informasi yang ditampilkan pada tabel 4.3 gambaran tingkat kecemasan ibu hamil pada masa pandemic Covid-19 paling banyak kategori normal, yaitu 96 responden $(96 \%)$

Hubungan tingkat pengetahuan dengan kecemasan ibu hamil di masa pandemi Covid-19

Tabel 4 Tabel silang tingkat pengetahuan dengan kecemasan ibu hamil di masa pandemi Covid-19

\begin{tabular}{lll}
\hline $\begin{array}{l}\text { Karakteristik } \\
\text { Responden }\end{array}$ & $\begin{array}{l}\text { Frekuens } \\
\text { i (f) }\end{array}$ & $\begin{array}{l}\text { Pe } \\
\text { rse } \\
\text { n } \\
\text { ( }\end{array}$ \\
& & ) \\
& & \\
& & 13 \\
\hline Usia & 13 & 84 \\
$\quad<20$ tahun & 84 & 3 \\
tahun & 3 & 1 \\
$\quad>35$ tahun & & 0 \\
Pendidikan & 1 & 11 \\
$\quad$ Tidak Sekolah & 0 & 64 \\
Tamat SD & 11 & 24 \\
Tamat SMP & 11 & \\
Tamat SMA & 64 & 75 \\
Tamat PT & 24 & 25 \\
Pekerjaan & & \\
Bekerja & 75 & 19 \\
Tidak Bekerja & 25 & 62 \\
Usia Kehamilan & & 19 \\
TW I & 19 & \\
TW II & 62 & 59 \\
TW III & 19 & 40 \\
Paritas & & 1 \\
Primigravida & 59 & \\
Multigravida & 40 & \\
Grandemultigravi & 1 & \\
da & & \\
\hline
\end{tabular}

Berdasarkan tabel 4 didapatkan hasil bahwa ibu hamil dengan tingkat pengetahuan baik yang memiliki kategori normal dalam tingkat kecemasan sebanyak 91 orang, dengan tingkat kecemasan ringan sebanyak 1 orang. Ibu hamil dengan tingkat pengetahuan cukup memiliki kategori normal dalam tingkat kecemasan sebanyak 5 orang, dan kecemasan ringan sebanyak 3 orang. Berdasarkan hasil analisa data dengan uji chi square didapatkan nilai significancy 0,001 . Berdasarkan nilai

Jurnal Riset Kesehatan Nasional hal. 96 
tersebut karena nilai $\mathrm{p}<0,05$ dapat diambil kesimpulan bahwa ada hubungan antara tingkat pengetahuan dengan kecemasan ibu hamil di masa pandemi Covid-19.

\section{PEMBAHASAN}

Karakteristik Ibu Hamil Berdasarkan usia

Berdasarkan hasil penelitian, usia responden terbanyak adalah diantara 20-35 tahun, yaitu 84 responden (84\%) terdapat responden dengan resiko tinggi usia $<20$ tahun sebanyak 13 orang $(13 \%)$ dan usia $>35$ tahun sebanyak 3 orang (3\%). Usia ibu merupakan salah satu faktor risiko yang berhubungan dengan kualitas kehamilan. Usia yang paling aman atau bisa dikatakan waktu reproduksi sehat adalah antara umur 20 tahun sampai umur 30 tahun. Penyulit pada kehamilan remaja salah satunya pre eklamsi lebih tinggi dibandingkan waktu reproduksi sehat. Keadaan ini disebabkan belum matangnya alat reproduksi untuk hamil, sehingga dapat merugikan kesehatan ibu maupun perkembangan dan pertumbuhan janin. Umur seseorang dapat mempengaruhi keadaan kehamilannya. Bila wanita tersebut hamil pada masa reproduksi, kecil kemungkinan untuk mengalami komplikasi di bandingkan wanita yang hamil dibawah usia reproduksi ataupun diatas usia reproduksi (Rikadewi, 2010). Menurut Marmi (2011) juga menegaskan bahwa umur termasuk faktor yang sangat berpengaruh dalam pencapaian peran wanita sebagai seorang ibu. Kehamilan yang terjadi pada usia reproduksi sehat tepat sesuai dengan perkembangan psikologi seorang wanita. Pada usia ini, seorang wanita akan mudah untuk beradaptasi dengan perannya sebagai seorang ibu. Semakin tinggi tingkat pendidikan seseorang maka semakin mudah menerima informasi sehingga banyak pula pengetahuan yang dimiliki.

\section{Karakteristik Ibu Hamil Berdasarkan Tingkat Pendidikan}

Berdasarkan hasil penelitian, ibu hamil memiliki latar belakang pendidikan yang paling banyak adalah tamat SMA, yaitu 64 responden (64\%). Namun masih ada yang tidak pernah bersekolah yaitu 1 responden (1\%). Pendidikan dengan tingkat pengetahuan seseorang sangat terkait, pengetahuan merupakan hal yang sangat penting untuk terbentuknya sebuah perilaku (Notoadmodjo, 2010). Tingkat pengetahuan ibu hamil sangat berperan dalam upaya menurunkan angka kematian ibu dan angka kematian bayi, sebab berdasarkan pengalaman dan penelitian ternyata perilaku yang didasari pengetahuan akan lebih bereksinambungan daripada perilaku yang tidak didasari dengan pengetahuan.

\section{Karakteristik Ibu Hamil Berdasarkan Pekerjaan}

Berdasarkan pekerjaan, ibu hamil yang bekerja dan tidak bekerja yang datang untuk melakukan pemeriksaan lebih banyak yang bekerja 75 responden (75\%). Pekerjaan tidak berperan dalam menentukan ibu hamil dalam melakukan kunjungan ibu hamil. Ini sejalan dengan penelitian dari Widiantari, 2015 bahwa pekerjaan tidak berpengaruh terhadap kunjungan ibu hamil dalam melakukan kegiatan senam hamil. Sehingga walaupun ibu hamil bekerja namun jika ibu memiliki pengetahuan yang baik, ibu akan meluangkan waktunya untuk melakukan pemeriksaan dan melakukan kegiatan yang berpengaruh positif bagi ibu dan bayinya.

\section{Karakteristik Ibu Hamil Berdasarkan Usia Kehamilan}

Berdasarkan hasil penelitian, ibu hamil yang datang paling banyak dengan usia kehamilan triwulan kedua sebanyak 59 responden $(59 \%)$. Ibu hamil pada triwulan II kondisi ibu maupun janin menjadi lebih stabil, biasanya pada masa ini ibu sangat menikmati kehamilannya sehingga ibu hamil akan lebih percaya diri untuk melakukan pemeriksaan kehamilan dan kegiatan di luar rumah (Dindia, 2016). Hal ini sesuai dengan pendapat yang dikemukakan Stopard (2009) bahwa pada usia kehamilan memasuki 20 minggu, ibu akan mendapatkan energi kembali dan keceriaan setelah mengalami rasa mual diusia kehamilan sebelumnya. Hal ini membuat ibu semangat untuk beraktivitas.

\section{Karakteristik Ibu Hamil Berdasarkan Paritas}

Berdasarkan hasil penelitian didapatkan bahwa paritas yang paling banyak adalah paritas 1 (ibu hamil pertama) sebanyak 59 orang $(59 \%)$. Berdasarkan penelitian yang dilakukan oleh Ana Wigunantiningsih tahun 2012, dengan hasil terdapat hubungan signifikan antara paritas dengan tingkat pengetahuan ibu hamil tentang ANC. paritas dilihat dari jumlah kehamilan ibu (gravida), gravida adalah merupakan jumlah kehamilan yang pernah dialami oleh seorang wanita. Hal ini

Jurnal Riset Kesehatan Nasional hal. 97 
berkaitan dengan pengalaman sehingga diharapkan semakin sering seorang wanita hamil maka pengetahuan akan ANC semakin baik, sehingga diharapkan tingkah lakunya juga semakin baik. Orang yang mempunyai pengetahuan lebih baik akan melakukan sesuatu dengan lebih baik dari orang yang tingkat pengetahuannya kurang, hubungannya dengan ANC diharapkan jika ibu hamil mengetahui tentang ANC maka akan memiliki perilaku yang baik dalam ANC yang ditunjukkan dengan melakukan ANC secara teratur dengan kesadaran sendiri bukan karena dorongan orang lain ataupun tenaga kesehatan.

\section{Gambaran tingkat pengetahuan ibu hamil tentang kehamilan pada masa pandemic Covid-19}

Pengetahuan (knowledge) adalah hasil tahu dari manusia, yang sekedar menjawab pertanyaan "what" misalnya apa air, apa manusia, apa alam, dan sebagainya (Notoadmodjo, 2012). Berdasarkan hasil penelitian paling banyak ibu hamil memiliki pengetahuan baik sejumlah 92 orang $(92 \%)$. Banyak nya ibu hamil yang berpengetahuan baik dikarenakan ibu yang mau untuk mencari informasi seputar kehamilan maupun persalinan pada masa pandemi, hal ini juga di pengaruhi oleh pendidikan ibu yang sebagian besar adalah tamat SMA sehingga pandai mencari informasi seputar kehamilan pada masa pandemi. Informasi yang sangat mudah didapatkan oleh ibu hamil seperti melalui media elektronik, media massa. Idealnya, pengetahun merupakan hal yang penting bagi ibu selama menjalani kehamilannya terutama terkait masa pandemi Covid-19 (Nwafor et al., 2020). Sebagaimana hasil penelitian yang dilakukan oleh Aniewke dkk (2020), menunjukkan bahwa mayoritas ibu hamil di Nigeria Utara memiliki pengetahuan yang baik (82\%). Namun sedikit berbeda dengan hasil penelitian yang dilakukan di Afrika, bahwa terdapat $60,9 \%$ ibu hamil memiliki pengetahuan yang adekuat tentang cara melindungi diri dari Covid-19 namun dalam praktisnya masih rendah yaitu sekitar 69,7\% (Nwafor et al., 2020). Pengetahuan merupakan faktor penting bagi ibu hamil karena dapat mempengaruhi perilaku ibu selama kehamilan. Sehingga sangat diharapkan edukasi yang optimal dari tenaga Kesehatan bagi ibu agar dapat menjalani masa kehamilannya dengan sejahtera sehingga ibu dan janin tetap sehat selama masa pandemi Covid-19 (Rizkia, M, $\mathrm{dkk}, 2020$ ).

Sumber informasi juga menjadi salah satu faktor lainnya yang berkaitan dengan perolehan pengetahuan dan perubahan perilaku yang baik bagi seseorang (Shing \& Brod, 2016). Karena berdasarkan hasil penelitian Nwafor et al., (2020), terdapat perbedaan antara tingkat pengetahuan ibu hamil yang mendapat edukasi secara formal dan rutin sebanyak enam kali selama hamil memiliki pengetahuan yang lebih baik dibandingkan ibu hamil yang tidak memperoleh informasi secara formal dari tenaga Kesehatan. Sehingga menurut Khoramabadi (2015), pemberian informasi yang lebih komprehensif bagi ibu hamil selama kunjungan kehamilan terkait cara menjaga kesehatannya selama menjalani kehamilan di masa pandemi Covid-19, baik berupa tanda gejala, prognosis, cara pengobatan, akses pelayanan yang cepat dan tepat, serta tata cara protokol kesehatan yang harus dipraktikkan dalam kehidupan sehari-hari (Khoramabadi et al., 2015). Dengan memiliki pengetahuan yang baik, ibu hamil juga akan terhindar dari cemas dan stress dalam kehamilan yang dapat mempengaruhi kesehatan ibu dan janin (BenAri et al., 2020). Sehingga hasil penelitian ini juga memberikan manfaat untuk tatatanan klinik yaitu sangat dibutuhkan edukasi dan pemberian informasi kesehatan secara berksinambungan (Al-Ateeq \& Al-Rusaiess, 2015). Edukasi sebagai sumber pendukung utama pelayanan dan perawatan kesehatan dengan melakukan pendekatan teurapeutik utama bagi ibu hamil terutama jika telah terkonfirmasi positif Covid-19.

Mahfoedz (2012) juga menjelaskan bahwa faktor-faktor yang mempengaruhi pengetahuan seseorang yaitu PKK, LKMD, koran/ majalah, TV, pengajian/persembahyangan dan puskesmas. Faktor media inilah yang memberikan ibu hamil konseling atau edukasi tentang kehamilan dan persalinan.

Menurut Pratitis (2013) dalam penelitiannya mengatakan bahwa kepatuhan melakukan antenatal care akan mempengaruhi tingkat pengetahuan ibu mengenai kehamilan dimana antenatal care ini ibu hamil banyak diberi konseling, penyuluhan atau informasi-informasi tentang kehamilan dan persalinan sehingga pengetahuan ibu bertambah.

Jurnal Riset Kesehatan Nasional hal. 98 
Gambaran tingkat kecemasan ibu hamil pada masa pandemic Covid-19

Berdasarkan hasil penelitian, ibu hamil yang datang paling sebanyak 96 orang (96\%) katergori normal dan ada 4 orang (4\%) yang dalam kategori cemas ringan. Kecemasan ringan ini berarti berhubungan dengan ketegangan akan peristiwa kehidupan seharihari (Rahmatiah, 2014). Pada tingkat ini lapangan persepsi melebar dan individu akan berhati-hati dan waspada.Walaupun jumlahnya tidak banyak namun kecemasan pada ibu hamil saat masa pandemi COVID19 perlu menjadi perhatian. Sebuah studi melaporkan bahwa pada masa pandemi COVID-19 ibu hamil yang mengalami kecemasan berat mencapai 57,5 \%, dan ada hubungan antara kecemasan ibu dengan kesiapan ibu hamil trimester 3 untuk menghadapi persalinan di masa pandemi COVID-19 (Angesti, 2020). Hal tersebut menunjukkan bahwa kecemasan ibu hamil, termasuk pada masa pandemi COVID-19 perlu penanganan secara tepat agar tidak mengganggu kesiapan menghadapi persalinan sehingga persalinan dapat berjalan dengan aman dan selamat.

\section{Hubungan tingkat pengetahuan dengan kecemasan ibu hamil di masa pandemi Covid-19}

Berdasarkan nilai tersebut karena nilai $\mathrm{p}$ $<0,05$ dapat diambil kesimpulan bahwa ada hubungan antara tingkat pengetahuan dengan kecemasan ibu hamil di masa pandemi Covid -19. Berdasarkan hasil ini dapat disimpulkan bahwa semakin baik pengetahuan, kecemasan ibu semakin baik (normal). Sesuai dengan penelitian yang dilakukan oleh Ervin, 2020 dimana hasil uji analisis statistic menjelaskan bahwa terdapat hubungan antara tingkat kecemasan ibu hamil trimester 3 dengan kesiapan melahirkan di masa pandemic COVID-19 ( $\mathrm{p}=0,00)$ dan ada hubungan antara tingkat pengetahuan dengan kesiapan menghadapi persalinan di masa pandemic COVID-19 ( $p=0,012)$. Menurut Stuart dan Sundeen dalam Linawati (2013) menjelaskan bahwa kecemasan yang dialami ibu hamil dalam menghadapi persalinan dapat dipengaruhi oleh beberapa faktor diantaranya tingkat ekonomi, tingkat pengetahuan, pendidikan dan dukungan keluarga. Rendahnya tingkat ekonomi,pengetahuan, pendidikan dan dukungan keluarga tentunya akan menimbulkan kecemasan ibu hamil dalam menyambut persalinan. Hal ini dipengaruhi oleh kondisi psikologis dan kurangnya pengetahuan tentang risiko persalinan yang menyebabkan ibu tidak dapat mengatasi kecemasannya. Berbeda dengan seorang multigravida yang sudah memiliki pengalaman sebelumnya sehingga dapat mengatasi kecemasannya. Bobak dalam Kusumawati juga diterangkan bahwa setiap kehamilan dan persalinan memiliki sifat dan kondisi yang berbeda sehingga kecemasan dapat terjadi pada primigravida maupun multigravida. Kemampuan ibu beradaptasi juga berperan dalam menciptakan kondisi psikologisnya. Primigravida tentunya lebih membutuhkan usaha keras daripada multigravida yang sudah berpengalaman sebelumnya. Jadi hasil analisa dalam penelitian ini kemungkinan lain yaitu karena masih adanya pengaruh dari paritas responden yang tidak dikontrol. Hasil penelitian menunjukkan bahwa sebagian dari ibu hamil mengalami kecemasan dalammenghadapi persalinan. Menurut Kushartanti, dkk. (2010), kegelisahan dan kecemasan selama kehamilan merupakan kejadian yang tidak terelakkan, hampir selalu menyertai kehamilan, dan bagian dari suatu proses penyesuaian yang wajar terhadap perubahan fisik dan psikologis yang terjadi selama kehamilan. Dengan makin tuanya kehamilan, maka perhatian danpikiran ibu hamil mulai tertuju pada sesuatu yang dianggap klimaks,sehingga kegelisahan dan ketakutan yang dialami ibu hamil akan semakin intensif saat menjelang persalinan (Aprianawati, 2007).

\section{KESIMPULAN DAN SARAN Kesimpulan}

Ada hubungan antara tingkat pengetahuan dengan kecemasan ibu hamil di masa pandemi Covid-19 dimana nilai $\mathrm{p}<0,05$. Berdasarkan hasil ini dapat disimpulkan bahwa semakin baik pengetahuan, kecemasan ibu semakin baik (normal).

\section{Saran}

Ibu hamil disarankan untuk lebih aktif untuk mencari informasi terbaru yang berkaitan dengan kesehatan ibu dan janin, terlebih lagi untuk mempersiapkan diri dalam menghadapi persalinan khususnya pada kondisi pandemic covid-19, serta tempat pelayanan kesehatan untuk mempertahankan pemberian pelayanan kebidanan sesuai protokol kesehatan, selalu memberikan edukasi pada pasien tentang melaksanakan protocol

Jurnal Riset Kesehatan Nasional hal. 99 
kesehatan dimana pun berada untuk mencegah penularan virus covid-19.

\section{KEPUSTAKAAN}

Angesti, E. P. W. (2020). Hubungan Tingkat Kecemasan Dan Pengetahuan Ibu Hamil Trimester 3 Dengan Kesiapan Menghadapi Persalinan Di Masa Pandemi COVID-19 Di Puskesmas Benowo Dan Tenggilis. (Skripsi). Surabaya: Universitas Airlangga.

Anikwe, C. C., Ogah, C. O., Anikwe, I. H., Okorochukwu, B. C., \& Ikeoha, C. C. (2020). Coronavirus disease 2019: Knowledge , attitude, and practice of pregnant women in a tertiary hospital in Abakaliki, southeast Nigeria. Gynecology Obstetrics, 151, 197-202. https:// doi.org/10.1002/ijgo.13293

Arifin. A., Rina Kundre., Sefti Rompas. (2015). Hubungan Dukungan Keluarga Dengan Kecemasan Ibu Hamil Menghadapi Proses Persalinan Di Puskesmas Budilitama Kecamatan Gadung Kabupaten Buol Propinsi Sulawesi Tengah. (Skripsi)

Ervina,P.W.A (2020) Hubungan Tingkat Kecemasan Dan Pengetahuan Ibu Hamil Trimester 3 Dengan Kesiapan Menghadapi Persalinan Di Masa Pandemi Covid-19 Di Puskesmas Benowo Dan Tenggilis. (Thesis), Universitas Airlangga.

Hartono. (2013). Psikologi Konseling Prenanda (cetakan pertama dan cetakan kedua). Jakarta : Media Group

Kemenkes RI. (2020). Pedoman Bagi Ibu Hamil, Bersalin, Nifas dan Bayi Baru Lahir di Era Pandemi COVID-19 Revisi 1. Jakarta : Kemenkes RI

Khoramabadi, M., Dolatian, M., Hajian, S., Zamanian, M., Taheripanah, R., Sheikhan, Z., Mahmoodi, Z., \& SeyediMoghadam, A. (2015). Effects of Education Based on Health Belief Model on Dietary Behaviors of Iranian Pregnant Women. In Global journal of health science (Vol. 8, Issue 2, pp. 230-239). http://www.embase.com/search/results? subac-

tion $=$ viewrecord\&from $=$ export\&id $=$ L61
58 28714\%0Ahttp://dx.doi.org/10.5539/ gjhs.v8n2p230

Putri. (2012). Hubungan Dukungan Sosial Keluarga Dengan Tingkat Kecemasan Ibu Hamil Primigravida Trimester III Menghadapi Persalinan Di BPS Ambarawati Desa Kebodalem Kec. Jambu. Kab. Semarang Email up2m@akbidngudiwaluyo (jurnal)

Nwafor, J. I. J. K. A., Okechukwu, B., \& Ikeotuonye, A. C. (2020). Knowledge and practice of preventive measures against COVID-19 infection among pregnant women in a lowresource African setting Johnbosco. https://doi.org/: https:// doi.org/10.1101/2020.04.15.20066894

Nursalam. (2016). Metodelogi Penelitian Ilmu Keperawatan;Pendekatan Praktis Edisi 4.Jakarta : Salemba Medika.

Rizkia, M, Mariatul, K , Dara, A, Darmawati , Aida, F, Nova, F. (2020). Hubungan Pengetahuan Dengan Perilaku Ibu Hamil Dalam Menjalani Kehamilan Selama Masa Pandemi Covid-19. Jurnal Keperawatan Malang Volume 5, No 2, 2020, 80-86

Sukarni, I. (2013). Kehamilan, Persalinan, Dan Nifas. Yogyakarta : Nuhu Medika

Stuart, G. W. (2013). Buku Saku Keperawatan Jiwa. Jakarta: EGC

Shodiqoh, E.R., \& Syahrul, F. (2014). Perbedaan Tingkat Kecemasan dalam Menghadapi Persalinan antara Primigravida dan Multigravida. Jurnal Berkala Epidemiologi. 2(1), 141-150. Diterima dari http:// www.jounal.unair.ac.id/download-full/ JBE8534-d73df33709fullabstr act.pdf pada tanggal 25 November 2020

Shahhosseini, Z.,Pourasghar,M.,Khalilian, A.,\&Salehi, F. (2015). A Review of the Effect of Anxiety During Pregnancy on Children's Health. Mater Sociomed.

Swarjana, I Ketut. 2013. Metodologi Penelitian Kesehatan. Yogyakarta : Andi Offset

Yuliani, Diki Retno.,Ulfah Musdalifah., \&Suparmi. (2017). Buku Ajar Aplikasi Asuhan Kehamilan Ter-update. Jakarta : Trans Info Media 